DOI:10.31142/ijahm/v8i4.01

Impact Factor: 4.415

\title{
Gandhaka Taila, Its Analytical Evaluation
}

\author{
${ }^{1}$ Aiswarya A , ${ }^{2}$ Nayak Dinesh J \\ ${ }^{1}$ P G student, P G Department of Rasashastra and Bhaishajya Kalpana, Muniyal Institute Of Ayurveda \\ Medical Sciences, Manipal \\ ${ }^{2}$ Professor, P G Department of Rasashastra and Bhaishajya Kalpana, Muniyal Institute of Ayurveda Medical \\ Sciences, Manipal \\ Corresponding author: Dr Aiswarya A, Muniyal Institute of Ayurveda Medical Sciences, Manipal,
} Karnataka, 576104

\begin{abstract}
:
Gandhaka Taila is a herbo-mineral preparation explained in various classical texts, mainly indicated in kushta. When the texts of Rasa Shastra were scrutinised, the nomenclature, Gandhaka taila is seen to be given for various preparations. The method of preparation is similar to that of Gandhaka Druti. Interestingly Rasendra Chintamani and Rasatarangini have explained a unique preparation of Gandhaka Taila. 3 batches of Gandhaka Taila were prepared to develop SOP (standard Operative Procedure) and samples were analysed with suitable analytical parameters. The 3 samples of Gandhaka Taila prepared showed almost similar results in all the analysis carried out.
\end{abstract}

Key words: gandhaka, gandhaka taila, analysis

\section{Introduction:}

Rasa Shastra is an integral part of Ayurveda, considering Lord Shiva as the creator of this Shastra. According to the classical texts of Rasashastra, aushadhi (medicines) are classified into Rasoushadhi (herbomineral/herbo-metallic preparations) and kashtoushadhi (herbal formulations). Rasoushadhi gained much importance due to its properties like, small dosage, palatability, quick action, and their lesser duration of administration.

Gandhaka (Sulphur), the most abundantly used drug among uparasa (a group of drugs in rasashastra) is well known for its efficacy in curing various diseases ${ }^{1}$. Gandhaka is been given prime importance along with parada, as it forms a base for various rasoushadhi. Shuddha Gandhaka (purified sulphur) has various qualities like rasayana, deepana, pachana and it is indicated in kushta, kandu, visarpa, dadru, krimi, visha etc. Shuddha Gandhaka is indicated both internally as well as externally.

Gandhaka Taila is a herbo-mineral preparation explained in various classical texts, mainly indicated in kushta, kshaya, pandu, swasa, kasa, shula, grahani ${ }^{2}$. Various references are available for the preparation of Gandhaka Taila. Some of the procedures for Gandhaka Taila are similar to the preparation of Gandhaka Druti. In Rasendra Chintamani, a preparation of Gandhaka Taila is explained where the process it undergoes is similar to that of preparation of a ghrita, under the context of Gandhaka Taila ${ }^{3}$.

Gandhaka after shodhana karma, in fine powder, is added into boiling milk, mixed well and kept for selfcooling. After cooling, little quantity of curd is added into the milk to prepare the curd. By churning curd the butter obtained is melted to get Gandhaka Ghrita. The obtained ghrita (ghee) is named as Gandhaka Taila. This formulation is indicated in kushta for both internal and external administration.

\section{Materials and Methods:}

All the required ingredients of Gandhaka Taila were procured, identified and authenticated to be of good quality, with the help of classical and modern physico-chemical parameters, prior to their use.

Pharmaceutical study

Table no: 1 showing list of ingredients 
${ }^{1}$ Aiswarya A, International Journal of Ayurvedic \& Herbal Medicine 8(4) July.-August. 2018 (3271-3277)

\begin{tabular}{|l|l|l|}
\hline Name Of The Drug & Description & Purpose \\
\hline Ashudhdha Gandhaka & Sulphur (S) & $\begin{array}{l}\text { Shodhana of } \\
\text { Gandhaka }\end{array}$ \\
\hline Go Ghrita & Cow Ghee & Preparation \\
\hline Shudhdha Gandhaka & Cow milk & Sulphur \\
\hline Go ksheera & Milk & \\
\hline Dadhi & Curd & \\
\hline Jala & Water & \\
\hline
\end{tabular}

Gandhaka taila was prepared in 3 batches following same procedure under similar conditions in order to develop SOP and to fix analytical standards.

20 litres of milk was taken in a mud pot and kept for boiling in mild fire. When foam started to appear at $100^{\circ} \mathrm{C}$, finely powdered Shuddha Gandhaka of $500 \mathrm{gm}$ was added and stirred well. After swanga sheetha (self-cooling), 1 litre of curd was added and the mixture was kept for fermentation. After complete curdling of milk, obtained curd was shifted to another vessel that was yellowish white in colour. In the bottom of pot, some sulphur was found that was precipitated.

The obtained curd was subjected to process of manthana (churning) by using wood churner. Gradually butter started to appear. After complete formation of butter, it was collected and weighed. After churning, the butter obtained was semisolid with the characteristic odour of sulphur with slight increase in $\mathrm{pH}$ of 5.6. All the features remain same after cleaning butter except $\mathrm{pH}$ which was 6.2. This obtained butter was subjected to mild heat and liquefied. It was later filtered using Cora cloth to obtain a condensed liquid form like Ghrita known as Gandhaka Taila.

All the samples took approximately 5 hours to boil the milk, 5 hours for swanga sheetha, 72 hours for fermentation and 5 hours taken for manthana process. 20-30 minutes for melting of butter.

Analytical study

All the 3 samples were analysed as it was essential to assure the quality of final product. We have followed organoleptic characters, physicochemical characters and advanced instrumental techniques of analysis such as FT $\mathrm{IR}^{4}, \mathrm{GC} \mathrm{MS}^{5}$, ICP OES ${ }^{6}$, particle size analysis. Particle size analysis was done by laser diffraction method $^{7}$.

\section{Result:}

Table no: 2 showing results of Gandhaka taila preparation

\begin{tabular}{|l|l|l|l|l|l|l|}
\hline Sample & $\begin{array}{l}\text { Quantity of } \\
\text { Gandhaka }\end{array}$ & $\begin{array}{l}\text { Quantity } \\
\text { of milk }\end{array}$ & $\begin{array}{l}\text { Quantity of } \\
\text { curd } \\
\text { obtained }\end{array}$ & $\begin{array}{l}\text { Quantity } \\
\text { of water } \\
\text { added }\end{array}$ & $\begin{array}{l}\text { Quantity of } \\
\text { Navaneetha } \\
\text { obtained }\end{array}$ & $\begin{array}{l}\text { Final } \\
\text { outcome }\end{array}$ \\
\hline Sample 1 & $500 \mathrm{gm}$ & 20 litres & 20.900 litre & 5 litre & $550 \mathrm{gm}$ & $299 \mathrm{gm}$ \\
\hline Sample 2 & $500 \mathrm{gm}$ & 20 litres & 20.950 litre & 5 litre & $660 \mathrm{gm}$ & $335 \mathrm{gm}$ \\
\hline Sample 3 & $500 \mathrm{gm}$ & 20 litres & 20.900 litre & 5 litre & $720 \mathrm{gm}$ & $360 \mathrm{gm}$ \\
\hline
\end{tabular}

Organoleptic characters

Table No: 3 showing organoleptic characters of gandhaka taila.

\begin{tabular}{|l|l|l|l|}
\hline Parameters & Sample 1 & Sample 2 & Sample 3 \\
\hline Colour & yellow & yellow & yellow \\
\hline Odour & Of gandhaka & Of gandhaka & Of gandhaka \\
\hline Taste & Madhura+ & Madhura+ & Madhura+ \\
\hline Consistency & Semisolid, oily & Semisolid, oily & semisolid, oily \\
\hline
\end{tabular}

Physico chemical parameters 
${ }^{1}$ Aiswarya A, International Journal of Ayurvedic \& Herbal Medicine 8(4) July.-August. 2018 (3271-3277)

Table no: 4 showing the analytical study result of Gandhaka taila sample 1

\begin{tabular}{|l|l|l|l|}
\hline Parameters & Initial & 3 months & 6 months \\
\hline Specific gravity & 0.940 & 0.942 & 0.942 \\
\hline Viscosity & 55.28 & 56.85 & 58.19 \\
\hline Refractive index & 1.486 & 1.486 & 1.486 \\
\hline Acid value & 1.671 & 1.720 & 2.222 \\
\hline Iodine value & 6.67 & 38.16 & 74.31 \\
\hline Saponification value & 70.032 & 131.21 & 222.26 \\
\hline Peroxide value & 0.797 & - & 1.193 \\
\hline Rancidity test & Negative & Negative & Slightly oxidized \\
\hline
\end{tabular}

Table no: 5 showing the analytical study result of Gandhaka taila sample 2

\begin{tabular}{|l|l|l|l|}
\hline Parameters & Initial & 3 months & 6 months \\
\hline Specific gravity & 0.916 & 0.916 & 0.918 \\
\hline Viscosity & 52.70 & 52.82 & 53.25 \\
\hline Refractive index & 1.485 & 1.485 & 1.485 \\
\hline Acid value & 1.667 & 1.725 & 2.859 \\
\hline Iodine value & 10.12 & 23.56 & 53.87 \\
\hline Saponification value & 86.580 & 115.613 & 201.984 \\
\hline Peroxide value & 0.780 & - & 0.991 \\
\hline Rancidity test & Negative & Negative & Oxidized \\
\hline
\end{tabular}

Table no: 6 showing the analytical study result of Gandhaka taila sample 3

\begin{tabular}{|l|l|l|l|}
\hline Parameters & Initial & 3 months & 6 months \\
\hline Specific gravity & 0.933 & 0.938 & 0.939 \\
\hline Viscosity & 59.64 & 60.02 & 62.13 \\
\hline Refractive index & 1.486 & 1.485 & 1.485 \\
\hline Acid value & 1.659 & 1.662 & 2.574 \\
\hline Iodine value & 10.87 & 28.32 & 56.65 \\
\hline Saponification value & 89.831 & 121.136 & 218.423 \\
\hline Peroxide value & 0.797 & - & 0.997 \\
\hline Rancidity test & Negative & Slightly oxidized & Completely oxidized \\
\hline
\end{tabular}

Instrumental parameters

Table no: 7 showing results of GC MS profile of gandhaka taila

\begin{tabular}{|l|l|l|l|}
\hline Parameters & Sample 1 & Sample 2 & Sample 3 \\
\hline Caproic acid & $0.74 \%$ & $0.77 \%$ & $0.87 \%$ \\
\hline Caprylic acid & $0.65 \%$ & $0.88 \%$ & $0.71 \%$ \\
\hline Capric acid & $1.75 \%$ & $2.71 \%$ & $1.78 \%$ \\
\hline 4-Decenoic acid & $0.19 \%$ & $0.21 \%$ & $0.19 \%$ \\
\hline Lauric acid & $2.53 \%$ & $4.81 \%$ & $2.65 \%$ \\
\hline
\end{tabular}


${ }^{1}$ Aiswarya A, International Journal of Ayurvedic \& Herbal Medicine 8(4) July.-August. 2018 (3271-3277)

\begin{tabular}{|l|l|l|l|}
\hline Tridecanoic acid & $0.06 \%$ & $0.26 \%$ & $0.05 \%$ \\
\hline Myristic acid & $10.03 \%$ & $10.97 \%$ & $10.70 \%$ \\
\hline Myristloeic acid & $0.90 \%$ & $0.80 \%$ & $0.88 \%$ \\
\hline Pentadecanoic acid & $1.27 \%$ & $1.98 \%$ & $1.37 \%$ \\
\hline 12-methyl tetradecanoic acid & $0.46 \%$ & $0.32 \%$ & $0.51 \%$ \\
\hline Palmitic acid & $35.96 \%$ & $32.90 \%$ & $37.05 \%$ \\
\hline Palmitoleic acid & $1.56 \%$ & $1.23 \%$ & $1.44 \%$ \\
\hline 14-methyl hexadecaneic acid & $0.76 \%$ & $0.74 \%$ & $0.81 \%$ \\
\hline Margaric acid & $0.60 \%$ & $0.70 \%$ & $0.63 \%$ \\
\hline Stearic acid & $14.55 \%$ & $12.95 \%$ & $15.99 \%$ \\
\hline Oleic acid & $21.98 \%$ & $23.05 \%$ & $19.58 \%$ \\
\hline Vaccenic acid & $3.57 \%$ & $1.43 \%$ & $3.20 \%$ \\
\hline Methyl-11,14-octadecadienoic acid & $1.36 \%$ & $2.75 \%$ & $1.26 \%$ \\
\hline Linolenic acid & $0.25 \%$ & $0.19 \%$ & $0.34 \%$ \\
\hline 9,12 octadecadienoic acid & $0.20 \%$ & $0.16 \%$ & $0.23 \%$ \\
\hline Archidic acid & $0.29 \%$ & $0.20 \%$ & $0.28 \%$ \\
\hline Lignoceric acid & $0.12 \%$ & & $0.11 \%$ \\
\hline Behenic acid & $0.21 \%$ & & $0.19 \%$ \\
\hline & & & \\
\hline
\end{tabular}

Table no: 8 showing particle size analysis value of Gandhaka Taila Sample 1

\begin{tabular}{|l|l|l|l|}
\hline Peaks & Diameter & \% Volume & Width $(\mathrm{nm})$ \\
\hline Peak 1 & 6.67 & 100 & 16.79 \\
\hline Peak 2 & 0.000 & 0.0 & 0.000 \\
\hline Peak 3 & 0.000 & 0.0 & 0.000 \\
\hline
\end{tabular}

Table no: 9 showing particle size analysis value of Gandhaka Taila Sample 2

\begin{tabular}{|l|l|l|l|}
\hline Peaks & Diameter & \% Volume & Width $(\mathrm{nm})$ \\
\hline Peak 1 & 30.77 & 44.6 & 36.94 \\
\hline Peak 2 & 5.16 & 55.4 & 8.94 \\
\hline Peak 3 & 0.000 & 0.0 & 0.000 \\
\hline
\end{tabular}

Table no: 10 showing particle size analysis value of Gandhaka Taila Sample 3

\begin{tabular}{|l|l|l|l|}
\hline Peaks & Diameter & \% Volume & Width $(\mathrm{nm})$ \\
\hline Peak 1 & 6.18 & 100 & 17.10 \\
\hline Peak 2 & 0.000 & 0.0 & 0.000 \\
\hline Peak 3 & 0.000 & 0.0 & 0.000 \\
\hline
\end{tabular}

Table no: 11 showing result of ICP AES

\begin{tabular}{|l|l|}
\hline Gandhaka taila & Percentage of Sulphur \\
\hline Sample 1 & $3.21 \%$ \\
\hline Sample 2 & $1.63 \%$ \\
\hline Sample 3 & $4.99 \%$ \\
\hline
\end{tabular}


${ }^{1}$ Aiswarya A, International Journal of Ayurvedic \& Herbal Medicine 8(4) July.-August. 2018 (3271-3277)

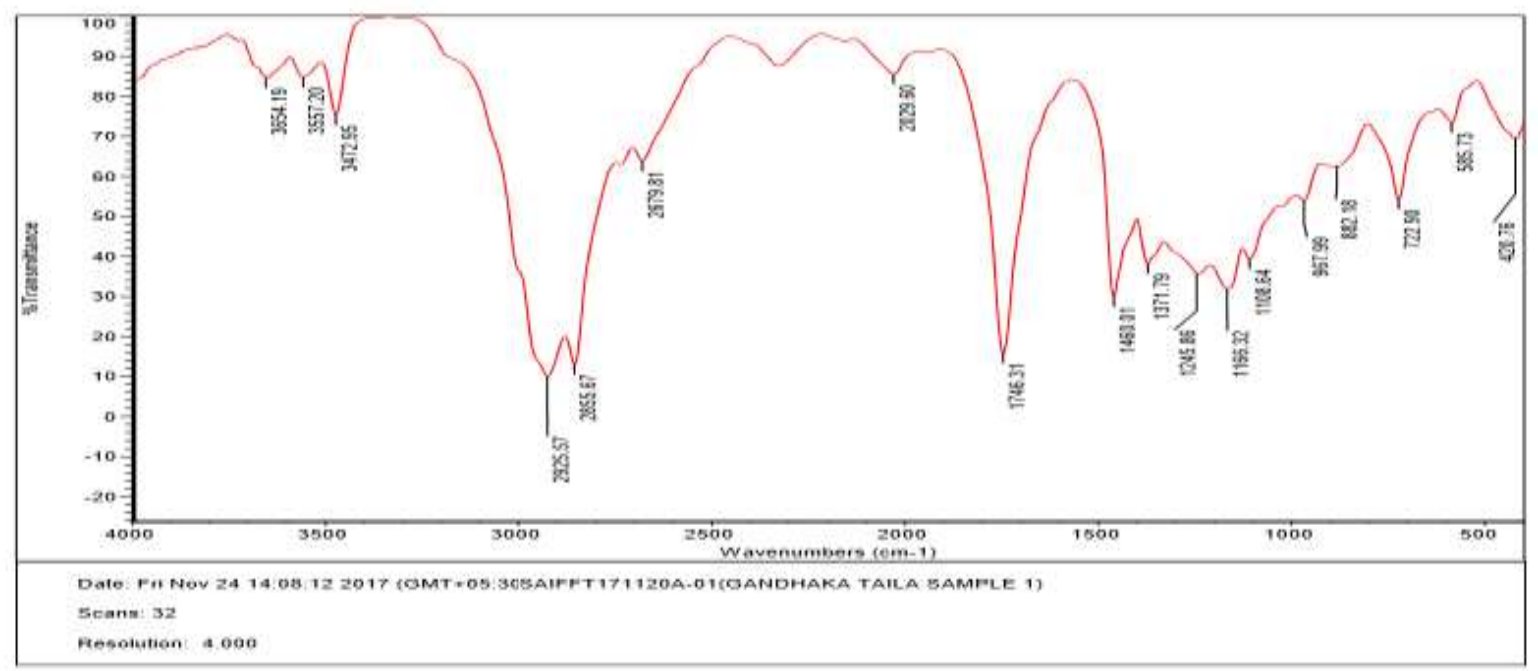

Fig

ure no: 1 showing FT IR result of Gandhaka Taila sample 1

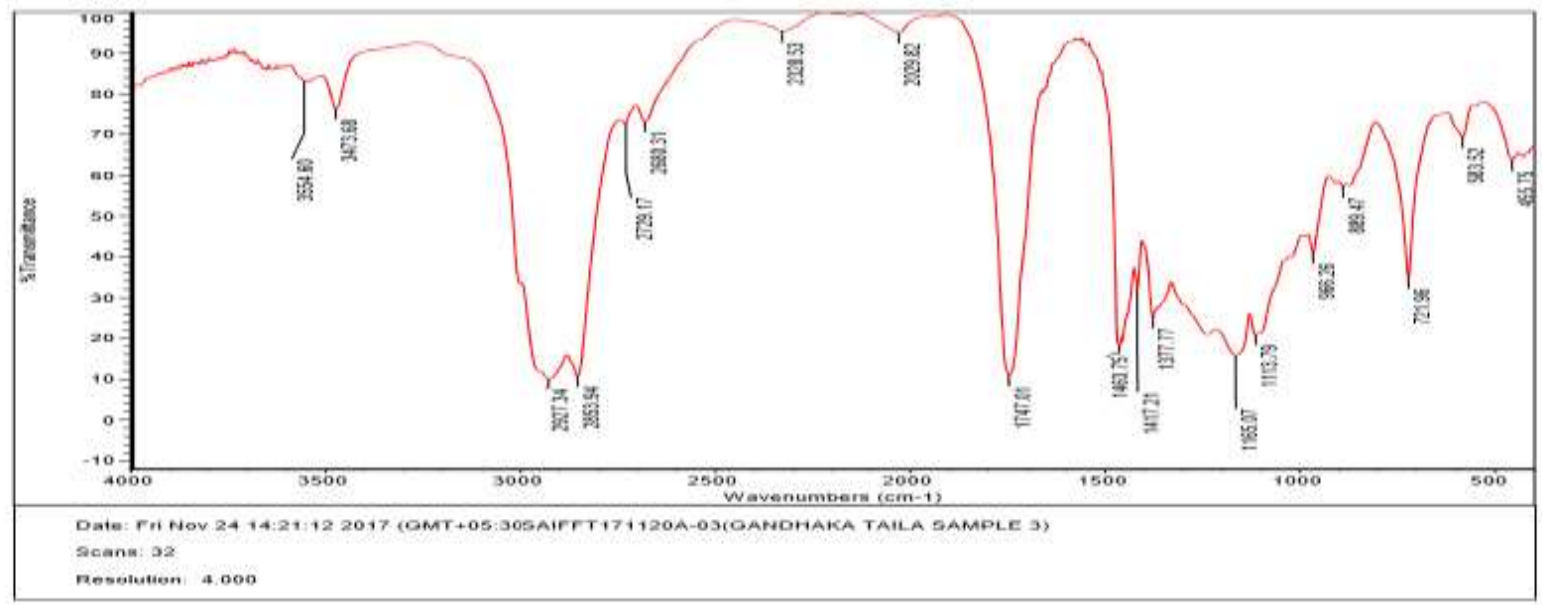

Figure no: 2 showing FT IR result of Gandhaka Taila sample 2

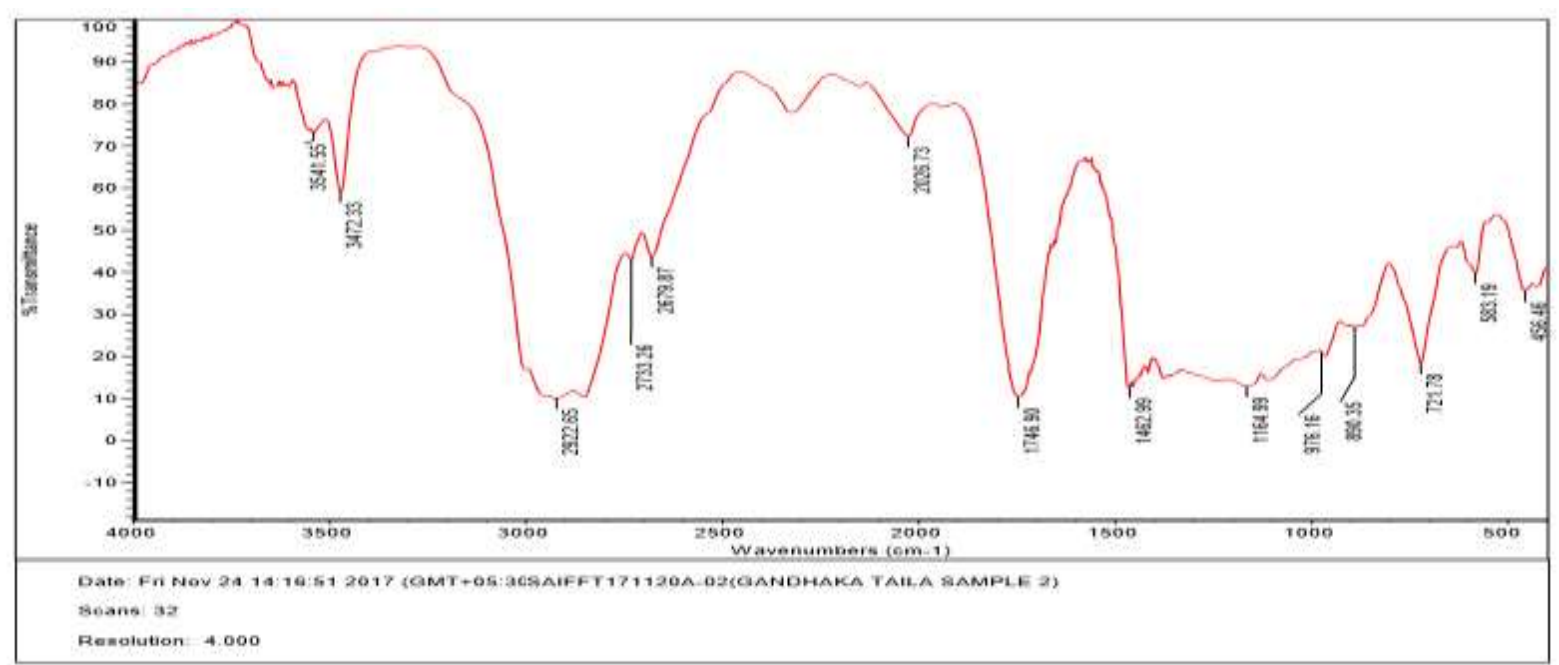

Figure no: 3 showing FT IR result of Gandhaka Taila sample 3 


\section{Discussion:}

All samples were yellow in colour with characteristic sulphur over it. On tasting, Madhura Rasa was perceived primarily. Consistency was unctuous semisolid.(Table 3)

Specific gravity of samples varies between $0.916-0.940$ to an average of 0.9296 . This result clearly indicates that specific gravity of all the samples were close to that of cow's ghee (0.93-0.94).

Viscosity of the samples was ranged between 52.70 to 59.64, with an average of 55.87. Sample 2 had

\section{Comparatively Lower Viscosity And Lower Specific Gravity.}

Refractive index of all the samples were almost similar i.e. 1.485-1.486. This is slightly higher than that of pure ghee (1.4545). Presence of dissolved sulphur might have increased the refractive index of the sample.

In this study, the acid values of sample were similar with an average of 1.666. It is possible that triglycerides had undergone slightly more hydrolysis due to more contact of heat.

Iodine values of the samples were 9.22 which is quiet less than that of pure ghee (26-28).

There was no major variation in saponification value among the samples (average 82.15). However slight lower value (70.32) was observed in sample.

Peroxide value of sample was on average of 0.791 . Rancidity test was negative for all samples. (Table $4,5,6)$ FT-IR spectra of sample 1 showed 18 peaks and sample 2 showed only 14 peaks. Maximum 19 peaks were observed in sample 3. Most of the peak values are similar among samples, indicating FT-IR is a useful technique for standardisation of Gandhaka Taila. Most of these peaks are characteristics of cow's ghee ${ }^{8}$. Peak between 2900-3000 per $\mathrm{cm}$ is mostly due to C-H stretch. The FT-IR spectra showed a distinct absorption between $966-968$ per $\mathrm{cm}$. It is the characteristics of trans- compounds (Figure 1,2,3). This indicates the presence of TFA in samples ${ }^{9}$.

In GC MS study, Gandhaka Taila samples has almost shown 23 peaks indicating the presence of 23 different fatty acids. Largest peak with an average of $35.50 \%$ of total area was corresponding to Palmitic acid. This is followed by Oleic acid, Stearic acid and Myristic acid respectively.(Table 7)

Particle size analysis was done following laser diffraction method. All samples had $100 \%$ Nano particles with diameter ranging from 17.1-36.94 $\mathrm{nm}$.(Table 8,9,10)

Concentration of sulphur varied in samples between $1.63 \%$ (sample 1) to $4.99 \%$ (sample 2) making an average of $2.28 \%$ (Table 11). This confirms the presence of sulphur in final product.

Shelf life study was carried out in $3^{\text {rd }}$ month and $6^{\text {th }}$ month. It was observed that specific gravity, refractive index and viscosity remained stable throughout the study. Acid value showed slight but progress increase (initially 1.671, after 3 months 1.720 and after 6 months 2.222 in sample 1, 1.667, 1.725 and 2.859 in sample 2, 1.659, 1.662 and 2.574 in sample 3). This nearly indicates that the amount of free fatty acids is progressively increasing along with time. Striking and progressive increase in iodine value was observed in all samples. This shows the increased degree of unsaturation and more tendency towards rancidity (table 4, $5,6)$.

Saponification value also shows a rapid tendency of progressive increase in all the samples, indicating the tendency towards more and more hydrolysis. Peroxide value also shows increase in all the samples at $6^{\text {th }}$ month even though the increase is marginal. This again shows the tendency towards rancidity (table $4,5,6$ ).

Test for rancidity was negative initially, slight oxidation was observed at the end of $3^{\text {rd }}$ month, but complete oxidation was observed at the end of $6^{\text {th }}$ month indicating the samples are rancid. Comparatively sample 1 was more stable, as it doesn't show any oxidation in $3^{\text {rd }}$ month and slight oxidation at $6^{\text {th }}$ month. However, a controlled real time stability test with more frequent analysis is required to confirm the shelf life of Gandhaka Taila (table 4, 5, 6).

\section{Conclusion:}

By evaluating the prepared samples using various analytical parameters, gandhaka taila samples are standardised. 


\section{${ }^{1}$ Aiswarya A, International Journal of Ayurvedic \& Herbal Medicine 8(4) July.-August. 2018 (3271-3277) References:}

1. Vagbhata; Rasa Ratna Samuchchaya; Translated With Tattvartha Bodinya Hindi Commentary By Dharmananda Sharmana; Motilal Banarasidas: Delhi; Reprint: 1999; P-39

2. Vagbhata; Rasa Ratna Samuchchaya; Translated With Tattvartha Bodinya Hindi Commentary By Dharmananda Sharmana; Motilal Banarasidas: Delhi; Reprint: 1999; P-41

3. Dhunduka Natha; Rasendra Chintamani; Translated With Siddhi Prada Hindi Commentary By Siddhinandan Mishra; Chaukamba Orientalia: Varanasi; Reprint. 2006; P-72.

4. Introduction To Fourier Transform Infrared Spectrometry; Thermonicolet; Medison; Page No 2-7

5. Wulshen TS Atal; Integration Of GCMS Methods For Differentiating Resin Preparation Methods; Analyst: May 2012: 137(9);2077-2085

6. Xiandeng Hou And Bradley T Jones; Encyclopedia Of Analytical Chemistry; John Wiley And Sons Ltd: Chichester; 2000; P-1-2

7. www.malvern.com/en/products/technology/laser-diffraction assessed on 29/1/2018

8. Bency Antony; Sourabh Shara; Bhavbhuti; Manoj Bhai Mehta; K Ratnam; K D Aparnathi; 2017; Study On FT-IR Spectra Of Ghee(Anhydrous Milk Fat); British Food Journal; Volume 119; Issue 1; P- 181-189

9. Alonsol; Fraga M J; Juarez M; Carmona T J; Journal Of Oil Chemistry Society; 79; 1-6(2002) 